\title{
EGFR NM_005228.3:c.2253_2276del24
}

National Cancer Institute

\section{Source}

National Cancer Institute. EGFR NM 005228.3:C.2253 2276del24. NCI Thesaurus. Code C98579.

A deletion of 24 nucleotides from the coding sequence of the EGFR gene from position 2253 through 2276. 